\title{
FRAKSI ETANOL RIMPANG TEMU PUTIH (Curcuma zedoaria (Christm.) Rosc.) SEBAGAI ANTIFUNGI TERHADAP Candida albicans dan Trichophyton rubrum
}

\author{
Antifungal Effect of Curcuma zedoaria Fraction Against Candida albicans and Trichophyton \\ rubrum
}

\author{
Yuli Wahyu Trimulyani, Nurma Suri, Niken Dwi Astarina \\ Jurusan Farmasi FMIPA, Universitas Tulang Bawang Lampung \\ E-mail : nikendwiastarina13@gmail.com \\ 087798444944
}

\begin{abstract}
Traditional medicine is used as natural because it has small effects and more economical than the synthetic drugs. One example of the plants used as a Traditional medicine are Curcuma zedoaria. The study to examine the activity fraction of Curcuma zedoaria rhizome ethanol extract agains Candida albicans and Trichophyton rubrum. The simplisia of Curcuma zedoaria rhizome was extracted with ethanol $70 \%$ using a maceration method. Thick extracts were then fractionated using saveral solven such as $n$-heksane, chloroform and ethanol. The testing method used disc antifungi activity with the concentration of $6.25 \%$, $12.5 \%, 25 \%, 50 \%, 75 \%$, ketokonazol as the positive control and aquades as the resolvent. The test compounds Thin Layer Chromatography (TLC) method with eluen chloroform: methanol: water $(2: 3: 5(\mathrm{~V} / \mathrm{V} / \mathrm{V}))$ and phase uses $\mathrm{G}_{60} F_{254}$ had been done. The result showed that Curcuma zedoaria rhizome significantly inhibit of $C$. albicans and $T$. rubrum the best inhibit zone diameter that are concentration of $75 \%$ for both of them with a diameter 8.98 $\mathrm{mm}$ in C. albicans and $11.66 \mathrm{~mm}$ in T. rubrum. Minimum Inhibitory Concentration (MIC) C. albicans is obtained on concentration of $6.25 \%$ and T. rubrum is concentration on of $12.5 \%$. The TLC results showed a compound of flavonoids (Rf 0.88), saponins (Rf 0.74), tannins ( $R f$ 0.86). Minimum Inhibitory Concentration (MIC) in $C$. albicans and T. rubrum are fungistatik and Minimum Bactericidal Concentration (MBC) are not fungisid for both of them. The ethanol fraction of Curcuma zedoaria rhizome has an activity as an antifungal against $C$. albicans and T. Rubrum with flavonoids, tannins and saponins.
\end{abstract}

Keywords: Antifungi, Candida albicans, Curcuma zedoaria, Fungistatic, Trichophyton rubrum.

\begin{abstract}
Abstrak
Pengobatan tradisional dengan menggunakan bahan alam banyak digunakan karena memiliki efek samping yang kecil dan lebih ekonomis dibandingkan pengobatan menggunakan obat sintetik. Salah satu contoh tanaman obat yang digunakan untuk pengobatan tradisional adalah tanaman temu putih. Rimpang temu putih mengandung senyawa flavonoid, saponin dan tanin yang bersifat sebagai antifungi. Tujuan dari penelitian ini adalah untuk membuktikan adanya aktivitas antifungi fraksi etanol rimpang temu putih terhadap Candida albicans dan Trichophyton rubrum. Proses ekstraksi dilakukan dengan
\end{abstract}




\section{JFL

cara maserasi menggunakan pelarut etanol $70 \%$. Ekstrak difraksinasi menggunakan pelarut n-heksan, kloroform dan etanol. Pengujian aktivitas antifungi menggunakan metode cakram dengan konsentrasi $6,25 \%, 12,5 \%, 25 \%, 50 \%, 75 \%$, kontrol positif ketokonazol dan kontrol negatif aquades dengan media Potato Dextrose Agar (PDA). Uji kandungan senyawa dilakukan dengan Kromatografi Lapis Tipis (KLT), fase diam menggunakan silika $\mathrm{G}_{60} \mathrm{~F}_{245}$ dan fase gerak kloroform:metanol:air $(2: 3: 5(\mathrm{v} / \mathrm{v} / \mathrm{v}))$. Hasil aktivitas antifungi fraksi etanol rimpang temu putih paling besar pada konsentrasi $75 \%$ dengan diameter zona hambat sebesar $8,98 \mathrm{~mm}$ untuk C. albicans dan $11,66 \mathrm{~mm}$ untuk T. rubrum. Konsentrasi Hambat Minimum (KHM) C. albicans diperoleh pada konsentrasi $6,25 \%$ dan T. rubrum pada konsentrasi $12,5 \%$. Hasil KLT menunjukkan adanya senyawa flavonoid (Rf 0,88), saponin (Rf 0,74), tanin (Rf 0,86). Berdasarkan uji Konsentrasi Hambat Minimum (KHM) dan Konsentrasi Bunuh Minumum (KBM) pada $C$. albicans dan T. rubrum hanya bersifat fungistatik dan tidak bersifat fungisid. Fraksi etanol rimpang temu putih memiliki aktivitas sebagai antifungi terhadap $C$. albicans dan $T$. Rubrum dengan senyawa flavonoid, tanin dan saponin.

Kata kunci : Antifungi, Candida albicans, Curcuma zedoaria, Fungistatik, Trichophyton rubrum

\section{PENDAHULUAN}

Indonesia merupakan salah satu negara kepulauan yang memiliki potensi dalam pengembangan dan pengolahan tanaman obat tradisional [1]. Pengobatan tradisional dengan menggunakan bahan alam banyak dipercaya karena memiliki efek samping yang kecil dan lebih ekonomis dibandingkan pengobatan menggunakan obat sintetik [2]. Salah satu contoh tanaman obat yang digunakan untuk pengobatan tradisional adalah tanaman rempah dari famili temutemuan yaitu temu putih (Curcuma zedoaria (Christm.) Roscoe.) [2].

Temu putih termasuk dalam famili Zingiberaceae, memiliki kandungan kimia dengan komposisi utama zedoarin [3]. Kandungan kimia lain yang dimiliki temu putih antara lain flavonoid, alkaloid, fenol, saponin, tanin, glikosida, steroid dan terpenoid yang dapat digunakan sebagai antimikroba, antifungi, antikanker, antialergi, antioksidan, antiinflamasi dan analgesik $[3,4]$. Antifungi adalah aktivitas suatu senyawa yang dapat menghambat atau membunuh jamur tertentu, sehingga antifungi ini diharapkan dapat menyembuhkan suatu penyakit yang disebabkan oleh jamur [4]. Pada umumnya obat antifungi berhubungan dengan biosintesis dan integritas ergosterol, sterol utama pada membran sel jamur. Kelompok lainnya mengganggu dinding sel jamur dan sintesis DNA intisel jamur [4]. Jamur yang dapat menyebabkan infeksi antara lain Candida albicans dan Trichophyton rubrum [4].

Infeksi penyakit kulit masih dominan terjadi di Indonesia dengan penggunaan antibiotik secara terus-menerus dan tidak tepat dapat menyebabkan resistensi [5]. Salah satu upaya pengobatan alternatifnya yaitu dengan pengembangan obat tradisional. Maka penelitian tentang ekstrak rimpang temu putih (Curcuma zedoaria (Christm.) Rosc.) ini penting dilakukan dari ektsrak ke fraksi agar diperoleh senyawa yang lebih spesifik dan konsentrasi terbaik sebagai antifungi terhadap $C$. albicans dan $T$. rubrum.

\section{METODE PENELITIAN}

\section{Alat}

Alat-alat yang digunakan dalam penelitian ini adalah alat-alat gelas, rotatory evaporator, autoklaf, ose, cawan petri, corong pisah, bunsen, jangka sorong, 
chamber, LAF, oven, plat silika gel $\mathrm{G}_{60} \mathrm{~F}_{254}$, lampu UV, kertas cakram dan cutton buds.

\section{Bahan}

Bahan-bahan yang digunakan adalah Rimpang temu putih (Curcuma zedoaria (Christm.) Rosc.), biakan jamur C. Albicans, T. rubrum, etanol $70 \%\left(\mathrm{C}_{2} \mathrm{H}_{6} \mathrm{O}\right)$, kloroform $\left(\mathrm{CHCl}_{3}\right)$, n-heksan $\left(\mathrm{CH}_{3}\left(\mathrm{CH}_{2}\right)_{4} \mathrm{CH}_{3}\right)$, aquadest $\left(\mathrm{H}_{2} \mathrm{O}\right)$, ekstrak kentang, cakram ketokonazol, dextrose, agar-agar, ampisilin, $\mathrm{FeCl}_{3}$, amonia, Liebermann Burchad.

\section{Prosedur Penelitian}

\section{Pengambilan bahan uji}

Tanaman yang digunakan pada penelitian ini adalah rimpang temu putih yang diperoleh dari Desa Purwosari Kec. Batanghari Nuban Kab. Lampung Timur.

\section{Pembuatan simplisia}

Pembuatan simplisia rimpang temu putih diawali dengan pengambilan rimpang temu putih segar. Setelah itu, rimpang temu putih dibersihkan dari kotoran yang menempel dengan air mengalir lalu ditiriskan, rimpang temu putih lalu ditimbang sebanyak $5 \mathrm{~kg}$ kemudian dirajang, lalu rimpang dikeringkan di bawah sinar matahari dengan ditutupi kain berwarna gelap hingga kering lalu disortasi kering, simplisia yang di dapat sebanyak kemudian dimasukkan ke dalam wadah bersih dan ditutup rapat.

\section{Uji parameter non spesifik simplisia}

\section{a. Kadar Air Simplisia}

Masukan lebih kurang $10 \mathrm{~g}$ ekstrak dan timbang seksama dalam cawan porselen yang telah ditara. Keringkan pada suhu $105^{\circ} \mathrm{C}$ selama 5 jam dan didinginkan dalam desikator lalu ditimbang.

\section{b. Kadar Abu Simplisia}

Lebih kurang $2 \mathrm{~g}$ sampai $3 \mathrm{~g}$ ekstrak yang telah digerus dan ditimbang seksama dimasukan kedalam krus porselen yang telah ditara ratakan yaitu dengan cara kurs porselen yang kosong dipanaskan kemudian didinginkan dalam desikator lalu di timbang.

\section{c. Kadar Abu Tidak Larut Asam}

Abu yang diperoleh pada penetapan kadar abu, didihkan dengan $25 \mathrm{ml}$ asam sulfat $\left(\mathrm{H}_{2} \mathrm{SO}_{4}\right)$ encer selama 5 menit, kumpulkan bagian yang tidak larut dalam asam, saring melalui krus kaca masir atau kertas saring bebas abu, cuci dengan air panas, pijarkan hingga bobot tetap, dinginkan dalam desikator lalu timbang.

\section{Pembuatan ekstrak etanol rimpang temu putih}

Simplisia rimpang temu putih (Curcuma zedoaria (Christm) Rosc.) yang telah dikeringkan ditimbang sebanyak 300 gram dimasukkan dalam wadah berwarna gelap dan dimaserasi dengan cairan penyari etanol $70 \%$ hingga merendam seluruh simplisia. Setiap 24 jam dilakukan pengadukan sesekali dan penggantian pelarut dengan cara penyaringan, ampas yang diperoleh kemudian dilakukan perendaman kembali dengan etanol $70 \%$, sedangkan maserat ditampung dalam botol penampung. Maserasi dilakukan sampai pelarut jernih. Untuk mengetahui zat tersari sempurna, maserat terakhir diambil sebanyak $5 \mathrm{ml}$, dimasukkan kedalam cawan porselen, kemudian dipanaskan diatas bunsen. Jika tidak terdapat endapan, maka maserasi dinyatakan tersari sempurna. Ekstrak yang didapat kemudian diuapkan dengan menggunakan alat rotary evaporator dengan suhu $60{ }^{\circ} \mathrm{C}$ sampai didapat ekstrak cair $100 \mathrm{ml}$ dan ditampung dalam botol berwarna gelap.

\section{Pembuatan fraksi etanol rimpang temu putih}

Ekstrak etanol cair yang didapat kemudian difraksinasi dengan menambahkan pelarut n-heksan, kloroform dan etanol secara sinambung dengan sifat kepolaran pelarut yang berbeda-beda dengan perbandingan 1:1. Ekstrak cair rimpang temu putih 
sebanyak $100 \mathrm{ml}$ dimasukkan kedalam corong pisah kemudian ditambahkan $100 \mathrm{ml}$ n-heksan, lalu dikocok hingga terbentuknya dua lapisan terpisah dan diperoleh fraksi $n$ heksan dan fraksi etanol. Lakukan sebanyak tiga kali pengulangan. Fraksi nheksan dipisahkan sedangkan fraksi etanol difraksinasi kembali dengan menambahkan $100 \mathrm{ml}$ kloroform, kocok menggunakan corong pisah hingga diperoleh fraksi kloroform dan fraksi etanol. Lakukan sebanyak tiga kali pengulangan. Fraksi etanol yang didapat kemudian diuapkan dengan hot plate suhu $60{ }^{\circ} \mathrm{C}$ hingga diperoleh fraksi etanol $30 \mathrm{ml}$ dan ditampung dalam botol berwarna gelap.

\section{Uji daya antijamur}

Uji daya antijamur dilakukan terhadap $C$. albicans dan $T$. rubrum dengan metode difusi yaitu metode cakram. Kertas cakram disiapkan, masing-masing kertas cakram direndam selama 3 jam dilarutan uji dengan konsentrasi $6,25 \%, 12,5 \%, 25 \%, 50 \%$ dan $75 \%$. Antibiotik yang digunakan Ketokonazol 2\% sebagai kontrol positif dan aquadest sebagai kontrol negatif. Uji daya antijamur menggunakan metode kertas cakram, media PDA dituangkan kedalam cawan petri yang telah ditambahkan dengan ampisilin. Ampisilin bertujuan menghambat bakteri kontaminasi yang tumbuh pada medium dan dibiarkan hingga memadat, kemudian ditambahkan suspensi bakteri $100 \mu \mathrm{L}$ lalu diratakan dengan cotton buds. Setelah itu, kertas cakram yang telah di rendam dangan larutan uji diletakkan pada permukaan media yang telah ditanami jamur. Inkubasi selama 24 jam pada temperatur $25{ }^{\circ} \mathrm{C}$. Pengamatan dilakukan dengan mengukur zona hambat terbukti disekeliling kertas cakram dengan menggunakan jangka sorong dalam satuan milimeter $(\mathrm{mm})$ dan perlakuan dilakukan sebanyak tiga kali.

\section{Uji KHM dan KBM}

Pengujian daya hambat fraksi rimpang temu putih akan disiapkan dengan beberapa tabung reaksi yang berisi $1,9 \mathrm{ml}$ PDB yang telah ditambahkan dengan ampisilin yang mengandung larutan uji dengan konsentrasi terendah yang memberikan daya hambat pada uji daya antifungi dan $0,1 \mathrm{ml}$ suspensi jamur $C$. albicans dan $T$. rubrum. Selain itu siapkan 3 tabung reaksi sebagai :

a. Kontrol media: Berisi $2 \mathrm{ml}$ media PDB

b. Kontrol larutan uji: Berisi media PDB 1,8 $\mathrm{ml}+0,2 \mathrm{ml}$ larutan uji.

c. Kontrol Jamur: Berisi $1,9 \mathrm{ml}$ media PDB $+0,1 \mathrm{ml}$ suspensi jamur.

Masing-masing tabung diinkubasi selama 24 jam. Pengamatan dilakukan dengan membandingkan kekeruhan media. Tabung reaksi yang jernih selanjutnya dibiakan kembali pada media tanpa penambahan mikroba uji ataupun agen mikroba, dan diinkubasi selama 24 jam.

\section{Pemisahan Senyawa Kromatografi Lapis Tips (KLT)}

Secara

Uji kandungan senyawa dengan KLT. Sampel yang akan digunakan yaitu Fraksi etanol rimpang temu putih. Fase diam yang akan digunakan yaitu pelat silika gel $\mathrm{G}_{60} \mathrm{~F}_{254}$ dengan ukuran $7 \mathrm{~cm} \times 2,5 \mathrm{~cm}$ yang diaktifkan terlebih dahulu dengan pemanasan dalam oven pada suhu $100^{\circ} \mathrm{C}$ selama 30 menit. Fase gerak yang digunakan yaitu kloroform, metanol dan air dengan perbandingan 2:5:3 v/v/v. Kemudian pelat silika ditotolkan sampel menggunakan pipa kapiler sebanyak tiga kali ulangan. Dibiarkan beberapa menit hingga kering dan masukkan ke dalam chamber yang telah jenuh dengan fase gerak yang digunakan. Plat KLT dikeluarkan noda yang tampak pada kromatogram kemudian diamati pada UV dengan panjang gelombang $254 \mathrm{~nm}$ dan $366 \mathrm{~nm}$ [6]. Bercak dideteksi dengan pereaksi semprot Dragendroff untuk alkaloid dan akan menunjukkan warna merah, jingga atau coklat, amonia untuk flavonoid menunjukkan warna kuning, hijau, coklat atau merah muda dan Liebermann Burchad untuk saponin dan steroid akan menunjukan warna coklat kehijauan atau biru [6]. Untuk mengetahui senyawa tanin dapat digunakan larutan $\mathrm{FeCl}_{3}$ dengan perubahan warna coklat kekuningan dari larutan $\mathrm{FeCl}_{3}$ 
menjadi coklat kehijauan atau biru kehitaman [7].

\section{KLT-Bioautografi}

Senyawa aktif yang mempunyai aktivitas antijamur kemudian dideteksi menggunakan metode bioautografi dengan cara kromatogram ditempelkan pada permukaan media agar sabaroud dalam petri yang masing-masing telah diinokulasi dengan suspensi jamur $C$. albicans dan $T$. rubrum. Setelah 1 jam lempeng tersebut diangkat dan dipindahkan kemudian diinkubasi pada suhu $25{ }^{\circ} \mathrm{C}$ selama 24 jam lalu amati zona hambatan yang terbentuk [7].

\section{Analisis data}

Data hasil pengamatan fraksi etanol ekstrak rimpang temu putih terhadap aktivitas antifungi $C$. albicans dan $T$. rubrum dianalisis menggunakan rancangan acak lengkap (RAL) two way dengan 3 (tiga) kali pengulangan. Kemudian dianalisis dengan metode Analisis Of Varian (ANOVA) untuk mengetahui ada tidaknya perbedaan zona hambat fraksi etanol rimpang temu putih yang akan diujikan terhadap $C$. albicans dan $T$. rubrum. Dilanjutkan dengan Uji Duncan. Analisis ini menggunakan software SPSS versi 24

\section{HASIL DAN PEMBAHASAN}

\section{Pembuatan simplisia}

Dari $5 \mathrm{~kg}$ rimpang temu putih segar diperoleh sebanyak 300 gr simplisa kering. Selanjutnya simplisia disimpan diwadah yang tertutup rapat.

\section{Uji parameter non spesifik simplisia}

Tabel 1 Hasil Uji Parameter Non Spesifik Simplisia

\begin{tabular}{c|c|c}
\hline Parameter & Hasil & Syarat \\
\hline Kadar Air & $7,62 \%$ & $\leq 10 \%$ \\
\hline Kadar Abu & $2,6 \%$ & $\leq 8,6 \%$ \\
\hline $\begin{array}{c}\text { Kadar Abu Tidak } \\
\text { Larut Asam }\end{array}$ & $2,6 \%$ & $\leq 2,9 \%$ \\
\hline
\end{tabular}

Pada tabel diatas dapat dilihat bahwa hasil uji parameter non spesifik terhadap simplisia rimpang temu putih telah memenuhi syarat standar mutu simplisia tumbuhan obat.

\section{Hasil ekstraksi}

Maserat yang diperoleh sebanyak 10,8 L kemudian diuapkan menggunakan rotary evaporator pada suhu $60^{\circ} \mathrm{C}$ hingga di dapat ekstrak cair sebanyak $100 \mathrm{ml}$ dengan warna merah bata pekat.

\section{Hasil fraksinasi}

Fraksi etanol yang di dapat dipekatkan menggunakan hotplate sehingga diperoleh fraksi etanol sebanyak $30 \mathrm{ml}$.

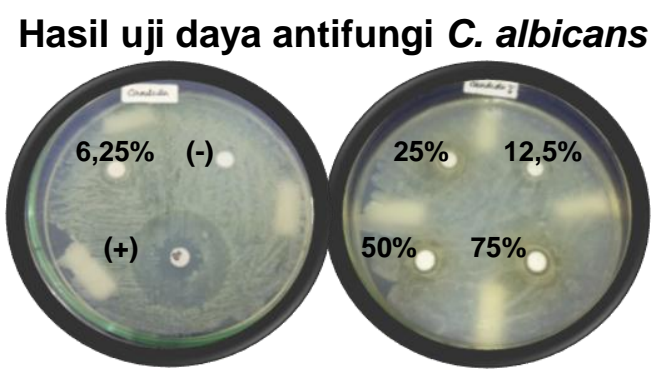

(A)

(B)

Gambar 1 Hasil uji daya antifungi fraksi etanol rimpang temu putih terhadap $C$. albicans (A) Konsentrasi 6,25\%, kontrol negatif $(-)$ aquades, kontrol positif (+) ketokonazol, (B) konsentrasi $75 \%, 50 \%, 25 \%$ dan $12,5 \%$.

Hasil penelitian uji daya antijamur fraksi etanol rimpang temu putih terhadap $C$. albicans memiliki zona hambat terbesar pada konsentrasi $75 \% \quad(8,98 \mathrm{~mm})$ dan terkecil pada konsentrasi $6,25 \%(6,55 \mathrm{~mm})$. Pada kontrol negatif yang hanya diberi aquades tidak menunjukkan adanya zona hambat dan pada kontrol positif yang diberi ketokonazol terdapat zona hambat sebesar $(30,98 \mathrm{~mm})$. Diameter zona hambat yang dimiliki oleh $C$. albicans termasuk dalam kategori lemah (5-10 mm) [9]. 
Setelah diperoleh data diameter zona hambat, dilakukan uji homogenitas secara statistik. Hasil dari uji homogenitas diperoleh data yang homogen, dimana nilai signifikan lebih besar dari 0,05 (0,270 > $0,05)$. Perlakuan pemberian fraksi etanol rimpang temu putih terhadap pertumbuhan C. albicans mempunyai pengaruh yang berbeda nyata. Hasil uji statistik one way ANOVA pada fungi uji terlihat bahwa nilai $f$ hitung $>f$ tabel $(526,751>3,69)$ dan $p$ (sig.) $=0,000$ oleh karena $p<0,05$ maka ada pengaruh perlakuan konsentrasi fraksi etanol rimpang temu putih terhadap pertumbuhan $C$. albicans.

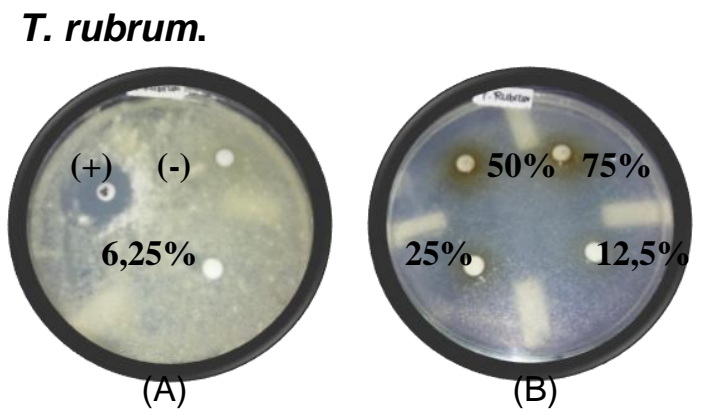

Gambar 2 Hasil uji daya antifungi fraksi etanol rimpang temu putih terhadap $C$. albicans (A) Konsentrasi 6,25\%, kontrol negatif () aquades, kontrol positif (+) ketokonazol, (B) konsentrasi 75\%, 50\%, $25 \%$ dan $12,5 \%$.

Tabel 2. Rata-rata diameter zona hambat fraksi etanolrimpang temu putih terhadap $C$. albicans dan T. rubrum

\begin{tabular}{c|c|c|c|c|c}
\hline \multirow{2}{*}{ Perlakuan } & \multicolumn{5}{|c}{ Diameter Zona Hambat (mm) } \\
\cline { 2 - 6 } & Ulangan & Ulangan & Ulangan & Rata-rata & Respon hambatan \\
& $\mathbf{1}$ & $\mathbf{2}$ & $\mathbf{3}$ & & - \\
\hline $\mathrm{K}(-)$ & 0 & 0 & 0 & $0 \pm 0,00^{\mathrm{a}}$ & Lemah \\
\hline $\mathrm{K} 6,25 \%$ & 6,46 & 6,42 & 6,78 & $6,55 \pm 0,62^{\mathrm{b}}$ & Lemah \\
\hline $\mathrm{K} 12,5 \%$ & 6,54 & 6,45 & 6,66 & $6,55 \pm 0,40^{\mathrm{b}}$ & Lemah \\
\hline $\mathrm{K} 25 \%$ & 6,86 & 6,56 & 7,67 & $7,03 \pm 0,58^{\mathrm{bc}}$ & Lemah \\
\hline $\mathrm{K} 50 \%$ & 8,69 & 7,55 & 8,7 & $8,31 \pm 1,17^{\mathrm{cd}}$ & Lemah \\
\hline $\mathrm{K} 75 \%$ & 9,21 & 8,24 & 9,51 & $8,98 \pm 0,96^{\mathrm{d}}$ & Sangat kuat \\
\hline $\mathrm{K}(+)$ & 30,74 & 31,05 & 31,15 & $30,98 \pm 0,63^{\mathrm{e}}$ & Sang \\
\hline
\end{tabular}

Keterangan :

Angka-angka pada kolom yang sama di ikuti huruf tika atas (dibelakang simpangan baku) tidak berbeda nyata pada taraf uji 5\% (uji Duncan).

Tabel 3. Diameter zona hambat fraksi etanol ekstrak rimpang temu putih terhadap T. rubrum.

\begin{tabular}{c|c|c|c|c|c}
\hline \multirow{2}{*}{ Perlakuan } & \multicolumn{5}{|c}{ Diameter Zona Hambat (mm) } \\
\cline { 2 - 6 } & $\begin{array}{c}\text { Ulangan } \\
\mathbf{1}\end{array}$ & $\begin{array}{c}\text { Ulangan } \\
\mathbf{2}\end{array}$ & $\begin{array}{c}\text { Ulangan } \\
\mathbf{3}\end{array}$ & Rata-rata & Respon hambatan \\
\hline $\mathrm{K}(-)$ & 0 & 0 & 0 & $0 \pm 0,00^{\mathrm{a}}$ & - \\
\hline $\mathrm{K} 6,25 \%$ & 0 & 0 & 0 & $0 \pm 0,00^{\mathrm{a}}$ & - \\
\hline $\mathrm{K} 12,5 \%$ & 7,74 & 8,97 & 9,61 & $8,77 \pm 0,92^{\mathrm{b}}$ & Lemah \\
\hline $\mathrm{K} 25 \%$ & 10,44 & 10,64 & 11,78 & $10,95 \pm 0,78^{\mathrm{c}}$ & Kuat \\
\hline $\mathrm{K} 50 \%$ & 10,13 & 11,62 & 12,82 & $11,52 \pm 1,00^{\mathrm{c}}$ & Kuat \\
\hline $\mathrm{K} 75 \%$ & 10,8 & 11,3 & 12,88 & $11,66 \pm 1,10^{\mathrm{c}}$ & Kuat \\
\hline $\mathrm{K}(+)$ & 28,21 & 29,89 & 30,21 & $29,43 \pm 1,07^{\mathrm{d}}$ & Sangat kuat \\
\hline
\end{tabular}




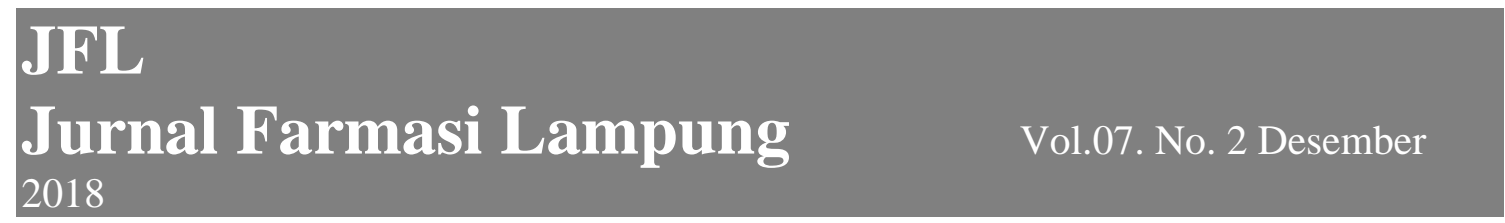

Keterangan :

Angka-angka pada kolom yang sama di ikuti huruf tika atas (dibelakang simpangan baku) tidak berbeda nyata pada taraf uji 5\% (uji Duncan).

Hasil penelitian uji daya antifungi fraksi etanol rimpang temu putih terhadap $T$. rubrum mempunyai zona hambat terkecil pada konsentrasi $12,5 \%(8,77 \mathrm{~mm})$ dan zona hambat terbesar pada konsentrasi $75 \%$ ( $11,66 \mathrm{~mm})$. Pada kontrol negatif yang hanya diberi aquades tidak menunjukkan adanya zona hambat dan pada kontrol positif yang diberi ketokonazol terdapat zona hambat sebesar $(29,43 \mathrm{~mm})$. Peningkatan konsentrasi mempengaruhi daya kerja zat antifungi terhadap pertumbuhan fungi. Hal ini desebabkan oleh semakin tingginya konsentrasi maka senyawa aktif terkandung lebih banyak dibandingkan konsentrasi rendah. Diameter zona hambat yang dimiliki oleh $T$. rubrum diameter zona hambatnya termasuk dalam kategori kuat $(10-20 \mathrm{~mm})$ [9]. Setelah diperoleh data diameter zona hambat, dilakukan uji homogenitas secara statistik. Hasil dari uji homogenitas diperoleh data yang homogen, dimana nilai signifikan lebih besar dari $0,05(0,071$ $>0,05)$. Perlakuan pemberian fraksi etanol rimpang temu putih terhadap pertumbuhan $T$. rubrum mempunyai pengaruh yang berbeda nyata.

Hasil uji statistik one way ANOVA pada fungi uji terlihat bahwa nilai $f$ hitung $>f$ tabel $(419,907>3,69)$ dan nilai $p$ (sig.) $=$ $0,000<0,05$ maka ada pengaruh perlakuan konsentrasi pada fraksi etanol rimpang temu putih terhadap pertumbuhan $T$. rubrum.

\section{Hasil uji KHM dan KBM}

Berdasarkan hasil pengujian KBM yang telah dilakukan maka tidak diperoleh nilai KBM untuk $C$. albicans konsentrasi $6,25 \%$ dan $T$. rubrum konsentrasi $12,5 \%$ dilihat dari tabel 4.4 bahwa hasil inkubasi dari penggoresan uji KHM pada media PDA menunjukkan adanya pertumbuhan fungi. Dapat disimpulkan bahwa KHM $C$. albicans konsentrasi 6,25\% dan T. rubrum konsentrasi $12,5 \%$ adalah $\mathrm{KHM}$ yang besifat fungistatik dan pada pengujian KBM tidak bersifat fungisid. Pada penelitian rimpang temu putih lainnya pada konsentrasi $50 \%$ memiliki daya bunuh terhadap pertumbuhan fungi $T$. mentagrophytes [5].

Berdasarkan uji ANOVA didapakan nilai kk sebesar $5 \%$ selanjutnya dilakukan uji lanjut dengan uji Duncan. Tabel hasil uji lanjut Duncan menunjukkan bahwa aktivitas antifungi pada semua konsentrasi baik konsentrasi fraksi etanol rimpang temu putih, kontrol positif dan kontrol negatif berbeda nyata. Diameter zona hambat yang terbentuk pada fraksi etanol rimpang temu putih dikedua fungi yaitu $C$. albicans dan $T$. rubrum lebih kecil dibandingkan dengan diameter zona hambat yang terbentuk pada kontrol (+) ketokonazol. Sehingga dapat disimpulkan bahwa fraksi etanol rimpang temu putih memiliki aktivitas antibakteri tetapi tidak lebih efektif dibandingkan dengan kontrol positif yaitu ketokonazol.

Tabel 3. Hasil uji konsentrasi hambat minimum fraksi etanol rimpang temu putih terhadap C. albicans

\begin{tabular}{c|c}
\hline Konsentrasi & $\begin{array}{c}\text { Pertumbuhan } \\
\text { C. Albicans }\end{array}$ \\
\hline $6,25 \%$ & - \\
\hline $5,25 \%$ & + \\
\hline $4,25 \%$ & + \\
\hline $3,25 \%$ & + \\
\hline $2,25 \%$ & + \\
\hline $1,25 \%$ & + \\
\hline kontrol media & - \\
\hline kontrol larutan uji & - \\
\hline \multicolumn{2}{c}{ kontrol fungi } \\
Keterangan : \\
Tanda (-) menunjukkan tidak adanya pertumbuhan \\
fungi \\
Tanda (+) menunjukkan adanya pertumbuhan fungi.
\end{tabular}


Tabel 4. Hasil uji konsentrasi hambat minimum fraksi etanol rimpang temu putih terhadap T. rubrum

\begin{tabular}{c|c}
\hline Konsentrasi & Pertumbuhan \\
\hline & T. rubrum \\
\hline $12,50 \%$ & - \\
\hline $11,50 \%$ & + \\
\hline $10,50 \%$ & + \\
\hline $9,50 \%$ & + \\
\hline $8,50 \%$ & + \\
\hline $7,50 \%$ & + \\
\hline $6,50 \%$ & + \\
\hline $4,50 \%$ & + \\
\hline $3,50 \%$ & + \\
\hline $2,50 \%$ & + \\
\hline $1,50 \%$ & + \\
\hline kontrol media & - \\
\hline kontrol larutan uji & - \\
\hline kontrol fungi & + \\
\hline \multicolumn{2}{c}{}
\end{tabular}

\section{Keterangan :}

Tanda (-) menunjukkan tidak adanya pertumbuhan fungi

Tanda (+) menunjukkan adanya pertumbuhan fungi.

\section{Hasil KLT}

Tabel 5. Hasil identifikasi fraksi etanol rimpang temu putih [10]

\begin{tabular}{c|c|c|c}
\hline Senyawa & Pereaksi & Hasil positif & $\begin{array}{c}\text { Hasil } \\
\text { penelitian }\end{array}$ \\
\hline Flavonoid & Amoniak & $\begin{array}{c}\text { Kuning, } \\
\text { hijau, } \\
\text { coklat, } \\
\text { merah }\end{array}$ & $\begin{array}{c}\text { Hijau } \\
(+)\end{array}$ \\
\hline Saponin & $\begin{array}{c}\text { Liebermen- } \\
\text { burchard }\end{array}$ & Hijau, biru & $\begin{array}{c}\text { Hijau } \\
(+)\end{array}$ \\
\hline Tanin & $\mathrm{FeCl}_{3}$ & $\begin{array}{c}\text { Coklat, biru } \\
\text { kehitaman }\end{array}$ & $\begin{array}{c}\text { Coklat } \\
(+)\end{array}$ \\
\hline
\end{tabular}

Hasil uji identifikasi kandungan metobolit sekunder dilakukan secara KLT terhadap fraksi etanol rimpang temu putih yaitu mengandung senyawa flavonoid, saponin dan tanin dengan nilai $\mathrm{Rf}$ berturut-turut yaitu $(0,88),(0,74)$ dan 0,86$)$.

Uji bioautografi dilakukan dengan bioautografi kontak dengan meletakkan lempeng kromatogram hasil evaluasi senyawa yang akan diuji di atas media padat yang sudah diinokulasi dengan mikroba uji. Hasil bioautografi fraksi etanol rimpang temu putih yang di uji dengan $C$. albicans dan T. rubrum dengan fase gerak berupa kloroform:metanol:air (2:5:3) $(\mathrm{v} / \mathrm{v} / \mathrm{v})$, menunjukkan adanya senyawa antimikroba ditandai dengan adanya daerah jernih yang tidak ditumbuhi mikroba.

\section{Hasil KLT-Bioautografi}

Hasil bioautografi fraksi etanol rimpang temu putih yang di uji dengan $C$. albicans dan $T$. rubrum dengan fase gerak berupa kloroform:metanol:air (2:5:3) (v/v/v), menunjukkan tidak adanya senyawa antimikroba ditandai dengan tidak adanya daerah jernih yang ditumbuhi mikroba.

Beberapa faktor yang mempengaruhi hasil dari pengujian secara KLT-Bioautografi dapat terjadi karena faktor human eror, salah satunya adalah konsentrasi yang terlalu kecil untuk menghambat pertumbuhan fungi menyebabkan tidak terbentuknya zona bening dimedia uji

\section{KESIMPULAN}

Berdasarkan hasil penelitian yang telah dilakukan dapat disimpulkan bahwa:

1. Fraksi etanol rimpang temu putih memiliki aktivitas sebagai antifungi terhadap C. albicans dan T. rubrum.

2. Konsentrasi terbaik fraksi etanol rimpang temu putih sebagai antifungi terhadap $C$. albicans dan $T$. rubrum yaitu pada konsentrasi $75 \%$. Konsentrasi Hambat Minimum pada $C$. albicans yaitu $6,25 \%(6,55 \mathrm{~mm})$ dan $T$. rubrum $12,5 \%(8,77 \mathrm{~mm})$

3. Fraksi etanol rimpang temu putih terbukti memiliki senyawa metabolit sekunder golongan flavonoid, saponin dan tanin.

\section{UCAPAN TERIMAKASIH}

Terimakasih kepada Staff Laboratorium Mikrobiologi Universitas Tulang Bawang Lampung. 


\section{DAFTAR PUSTAKA}

[1] Hartono Maiyani. 2011. Potensi Temu Putih (Curcuma zedoaria) Sebagai Antibakteri dan Kandungan Senyawa Kimia (skripsi). Bogor : Institut Pertanian Bogor.

[2] Siswani Tutik, Okid Paramana Astirin TW. 2003. Pengaruh ekstrak temu putih (Curcuma zedoaria Rosc.) terhadap spermatogenesis dan kualitas spermatozoa mencit (Mus musculus L.) (skripsi). Surakarta: Universitas Sebelas Maret. p. 38-42.

[3] Dalimarta Setiawan. 2003. Atlas tumbuhan obat Indonesia. Jilid 3. Jakarta: Puspa swara. p. 171-172.

[4] Nuryanti Siska. 2016. Aktivitas Antifungi Temu putih (Curcuma zedoaria) Terhadap Trichopython Mentagrophytes (skripsi). Universitas Muslim Indonesia Makasar.

[5] Wulandari Ratna. 2015. Pengaruh Pendidikan Kesehatan Tentang Penyakit Tinea Pedis Terhadap Pengetahuan dan Sikap Pada Petani Desa Jembungan (skripsi). Surakarta : Universitas Muhammadiyah Surakarta.

[6] Davis WW and T.S. 1971. Disc Plate Methods of Microbiological Antibiotic Assay. J. Microbiology. 659-665 p.

[7] Harborne JB. 1987. Metode Fitokimia Penuntun Cara Modern Menganalisis Tumbuhan. Edisi 2. Bandung: Institut Teknologi Bandung.

[8] Ros Sumarny. 2012. Kadar kurkumin dan Potensi Antioksidan Ekstrak Etanol Rimpang Temu Putih (Curcuma zedoaria), Temu Mangga (Curcuma mangga Val et Zyp), dan Temu Lawak (Curcuma xanthorrhiza
Roxb) Universitas Pancasila, Jakarta.

[9] Pratiwi S. 2008. Mikrobiologi Farmasi. Jakarta: Erlangga.

[10] Patimah Raudatul. 2010. Efek Antiinflamasi Infusa Rimpang Temu Putih (Curcuma zedoaria (Christm) Roscoe) Pada Tikus Putih Jantan (skripsi). Surakarta : Universitas Muhammadiyah Surakarta. 